\title{
THE STRATEGIC COMPETITIVENESS OF THE SOUTH AFRICAN MINING INDUSTRY IN THE AGE OF THE FOURTH INDUSTRIAL REVOLUTION
}

\author{
M.S. Zulu' ${ }^{1 *}$, M.W. Pretorius ${ }^{1} \&$ E. van der Lingen ${ }^{1}$
}

\section{ARTICLE INFO}

\section{Article details \\ Presented at the $32^{\text {nd }}$ annual conference of the Southern African Institute for Industrial Engineering (SAIIE), held from 4-6 October 2021 in Muldersdrift, South Africa. \\ Available online \\ 29 Nov 2021 \\ Contact details \\ Corresponding author u25405714@tuks.co.za \\ Author affiliations \\ 1 Department of Engineering and Technology Management, University of Pretoria, South Africa}

\section{ORCID® identifiers}

M.S. Zulu1

https://orcid.org/0000-0003-0475-4785

M.W. Pretorius

https://orcid.org/0000-0002-8214-4838

E. van der Lingen

https://orcid.org/0000-0003-1648-3564

\section{DOI}

http://dx.doi.org/10.7166/32-3-2627

\section{ABSTRACT}

The South African mining industry has a history of a range of major challenges, including high operating costs that have had a negative impact on mines' profitability and financial sustainability. The advent of Fourth Industrial Revolution technologies has opened up new opportunities for the mining industry, among other things, to improve its cost-effectiveness and future competitiveness. Most South African mining companies have begun to adopt Fourth Industrial Revolution technologies; however, quite a large number of their projects have not been successful. The main objective of the paper is to conduct an integrative literature review to determine why some of the companies in the minerals, mining, and processing industry have not been successful in implementing Fourth Industrial Revolution technologies. The findings of the study outline areas of organisational and technological capability on which the industry could focus when developing future innovation strategies.

\section{OPSOMMING}

Die Suid-Afrikaanse mynboubedryf het 'n geskiedenis van 'n reeks uitdagings, ingesluit hoë operasionele kostes, wat 'n negatiewe impak op myne se winsgewendheid en finansiële volhoubaarheid gehad het. Die koms van Vierde Industriële Rewolusie tegnologieë het nuwe geleenthede vir die mynboubedryf geskep, onder andere om koste-effektiwiteit en kompeterendheid te verhoog. Die meeste Suid-Afrikaanse mynbou maatskappye het begin om Vierde Industriële Rewolusie tegnologieë aan te neem, maar 'n groot aantal van hulle projekte was nie suksesvol nie. Die hoofdoelwit van dié artikel is om 'n geïntegreerde literatuuroorsig te doen oor hoekom sommige van die maatskappye in die minerale-, mynbou- en proses bedryf nie suksesvol was met die implementering van Vierde Industriële Rewolusie tegnologieë nie. Die bevindings van die studie beskryf areas van organisatoriese en tegnologiese vermoëns waarop die industrieë kan fokus wanneer hulle toekomstige innovasie strategieë ontwikkel.

Among other major challenges, South African mining companies are battling with high operating costs that have a negative impact on their profitability and their financial sustainability. Most of the mining industry's challenges directly or indirectly underpin the high operating costs. For example, the depletion of highgrade reserves results in high operating costs for consumables and energy, thus directly influencing mines' operating costs.

Modern mining companies are expected to align themselves with a balanced sustainable approach by ensuring that mining and processing methods, waste disposal, and energy consumption are cost-effective and do not negatively affect the ecosphere. In line with the challenges currently faced by the South African mining industry, the International Institute for Sustainable Development has also identified the key drivers of technological change in the mining industry: the need to improve the health and safety environment for mine workers; the need to reduce (existing) operating costs and to improve the productivity of assets and the efficiency of operations in the face of a global economic slowdown, shrinking margins, and pressure on 
cash flows; the need to reduce the costs of asset development as ore grades and accessibility decline while upfront capital costs rise; and the need to reduce the costs of technology development [1].

To take care of these issues and expectations simultaneously, the mining industry must embrace applicable Fourth Industrial Revolution (4IR)/digital transformation technologies.

The advent of 4IR (often called 'digital transformation') technologies is supposed to improve the costeffectiveness of all industries. It has been observed how the introduction of digital technologies has disrupted industry value chains and, in some instances, triggered firm-specific responses to technologydriven changes [2]. The popularity of digital transformation/4IR is driven by global competition and by the need for the fast adaptation of production to ever-changing market requests [3].

However, it is argued that, in terms of actual progress in the adoption of the 4IR, the mining and metals industry has been left behind [4]. Moreover, some mining and metals companies that have embraced the implementation of 4IR technologies have reported a relatively poor record of success, particularly when it comes to safeguarding against falling productivity and rising operating costs.

The reasons for recording relatively poor success in the implementation of 4IR technologies, particularly in the mining and metals industry, are not yet adequately covered or well-understood in scholarly studies. The number of failures in the implementation of 4IR means that there is an opportunity to investigate the areas where companies should prioritise the adoption of digital transformation, and to consider not only the technical aspects, but also the managerial, organisational, and human dimensions, including what types of novel business models and people skills are required for the future, and what change processes would make it happen.

This study focuses on the minerals, mining, and processing and related industries. The South African mining industry plays a critical role in making a socio-economic contribution; thus it is important for it to be aligned with the progressive technological developments brought about by 4IR/digital transformation phenomena. The socio-economic contribution of the mining industry in South Africa is notable because it includes, among other things, employment opportunities, contributions to tax income, increasing the value of the gross domestic product (GDP) and the rate of economic growth, and contributing to the country's balance of payments.

The following are some of the key socio-economic contributions made by the industry to the South African economy and to society at large: 453000 people were directly employed in the mining Industry; R22 billion was contributed to taxes, and R131 billion to employees' earnings; the direct contribution to the GDP was R351 billion, or 7.90 per cent of total GDP; R91 billion was a direct contribution to fixed investments; the total primary minerals sales equated to R475 billion, mineral export sales were valued at R312 billion, royalties came to R7.60 billion, and PAYE contributions by employees equated to R21 billion [5].

The current problem is that most companies that have implemented 4IR technology projects have not been successful. Previous studies estimated that, on average, 70 per cent of all digital transformation projects did not achieve their goals [6], [7], [8]. The mining industry is no exception. Yet the reasons for such a high failure rate are neither apparent nor well-understood by scholars.

Thus the main objectives of this study are:

1. To understand why some mining companies have not been successful in addressing their major challenges (such as high operating costs) by implementing 4IR technologies.

2. To understand what lessons could be learnt from other industries that have successfully implemented digital transformation technological initiatives.

This paper comprises a brief description of the research methodology used, the findings and a discussion of them, and the conclusions and recommendations.

\section{RESEARCH METHODOLOGY}

The research methodology used in this study is an integrative literature review (IRL). The main objective of an integrative literature review is to assess, critique, and synthesise the literature on a research topic such that new theoretical frameworks and viewpoints come to the fore [9], [10]. The research questions for the IRL can be narrowed or broadened, depending on the objective of the study. The literature search strategy may not necessarily be systematic. 
For this study, taking into consideration that digital transformation/4IR is a new and emerging topic, the intent is to understand and critique initial conceptualisations and theoretical frameworks rather than to review old theoretical models and frameworks.

According to many authors, an ILR demands more creative data collection simply because the objective, most of the time, is not to cover all the articles that have been published, but rather to integrate perspectives and insights from different fields or research disciplines [11], [12], [13].

The sample characteristics for an ILR include research articles, books, and other published scholarly works. The steps that are followed for this ILR include stating the research questions, identifying the relevant literature, summarizing the evidence, and interpreting the findings.

The research questions that are to be answered in line with the objectives are listed below:

1. Why do minerals, mining, and metals companies adopt digital transformation/4IR?

2. What are the challenges that companies encounter when adopting digital transformation?

3. What are the general success factors when implementing digital transformation?

4. What are the existing approaches to leading digital transformation initiatives?

\section{FINDINGS AND DISCUSSION}

\subsection{Fourth Industrial Revolution/digital transformation}

There are various definitions and descriptions by various scholars of what digital transformation/4IR is. However, there appears to be a good convergence among the definitions of various authors. Digital transformation/4IR is defined as the use of new digital technologies to enable major business improvements such as enhancing customers' experience, streamlining operations, or creating new business models [14]. Some definitions appear to put more emphasis on IT/ICT, which is essentially an enabler of digital transformation. From an IT/ICT point of view, 4IR is defined as the revolutionary change that occurs when IT proliferates in all industries - that is, in primary, secondary, and tertiary industries [15]. In other words, it is a result of the horizontal expansion of IT. But, most importantly, there are technologies that are key to enabling the development and implementation of digital transformation/4IR technological initiatives.

The 4IR/digital transformation can also be described as a new industrial paradigm that embraces a set of future industrial developments, including cyber-physical systems (CPS), the Internet of Things (IoT), the Internet of Services (IOS), robotics, big data, cloud manufacturing, and augmented reality [16]. This definition places more emphasis on the supporting technologies for the 4IR. From the South African mining industry viewpoint, digital transformation/4IR is defined as the technological developments that blur the lines between the physical, digital, and biological spheres. It essentially integrates cyber-physical systems and the Internets of Things, big data, cloud computing, robotics, artificial intelligence-based systems, and additive manufacturing [17].

The 4IR will undoubtedly shape business operations across all industries [4], [18], [19]. It is ubiquitous and will eventually transform and reshape all operations and production, management, governance, and products and services in all industries. It is asserted that digital transformation will eventually be the most powerful driver of innovation over the next few decades - until a new wave of innovation rolls in [20].

There is good convergence among many scholars that digital transformation has game-changing attributes for value-creation opportunities in all companies [21], 22], [23], [24]. It affects all facets and aspects of industrial production and services, such as productivity and efficiency [25], [26], [27], the digitisation of products and services [28], the intensity of automation [29], [30], [31], and intelligent manufacturing [32]. Digital transformation is also largely viewed as offering a much-needed strategic opportunity for companies to offer new products and services [33], [34], [35], [22].

What makes digital transformation ubiquitous in many companies and industries is that it allows, among other features, for interoperability, virtualisation, decentralised decision-making, real-time capability, a services orientation for service providers, and modularity. These are particularly important performance characteristics for all companies that conduct business in an era that is characterised by globalisation and high levels of business interconnectivity. 
In addition to the features of digital transformation listed above, one of the outstanding features is the integration of both horizontal and vertical production systems using ICT. This feature is particularly key, as it allows companies to stay competitive in the face of globalisation, high levels of competitiveness, market volatility, relatively shorter innovation and product life cycles, and the ever-increasing complexities of products and services [36], [37], [38]. And most importantly, digital transformation technologies can be retrofitted to business processes. Thus, it is imperative for any company that intends to compete effectively with its rivals to adopt and embrace digital transformation technological initiatives [39], [40], [41].

For the South African mining industry, the advent of digital transformation/4IR presents a new spectrum of opportunities to create entirely new ways of serving existing global mineral needs and of optimising existing industry value chains. It will afford the industry an opportunity to confront the new requirements of global competitive markets.

\subsection{Why do minerals, mining, and metals companies adopt digital transformation/4IR?}

Since the advent of the 4IR, companies have found themselves having to relook at how they have been doing business. The main question is, why do companies, including the mining industry, adopt digital transformation technological initiatives?

The decision to embrace digital transformation technological initiatives could be triggered for various reasons - e.g., purely process operational tasks, and/or being influenced by a company-wide strategy. In some instances, the company will find itself having no option but to transform digitally because digital transformation is happening along the value chain in which it operates (which is more of a bandwagon effect). It has been realised that, with the advent of the 4IR, many value chains are the objects of restructuring [42], [43].

Researchers have identified various possible triggers of digital transformation in several industries, including the use of digital transformation technologies in improving quality management processes, maximising productivity, and improving working conditions and product quality [4], [18], [44], [45]. Such reasons are purely operational, being meant to address the day-to-day operational issues of the company; they have no strategic or future-focused characteristics.

The triggers of digital transformation can also be viewed as mainly the need for better customer experience and engagement, operational improvements, and changes to business [14]. Many authors appear to view customers' behaviour, expectations, and satisfaction as a key driver of digital transformation in many industries [46], [47], [48], [49], [50], [51], [52].

Although many authors have identified the customer/buyer factor as one of the key drivers of the adoption of digital transformation, it is strange that buyers, new entrants in the market (who will essentially come with state-of-the-art technologies), and industry competitors are not clearly viewed as critical drivers of digital transformation. No scholarly work has been identified that aligns Porter's forces (which drive industry competition) with $4 \mathrm{IR}$. Interestingly, only a very few authors have recognised the competitive advantage brought about by the adoption of 4IR technological initiatives [49], [53].

The triggers of digital transformation will most likely vary between organisations and within sectors, as they are most likely to be defined by the major challenges that the company or industry experiences. Thus, some are purely industry-specific; in the South African mining industry, for example, the triggers of digital transformation are likely to be aligned with its current significant challenges, such as safety in the workplace, high operating costs and relatively low profitability, depleting high-grade reserves, regulatory requirements, and the need to meet sustainability goals.

A study conducted in Australian industries (which included mining, services, construction, manufacturing, and agriculture) to determine the triggers of digital transformation identified an interesting combination of reasons for it - some operational, and some strategic [54]. The triggers so identified were a customer focus and value differentiation, cost efficiency, process efficiency, environmental sustainability, workers' safety, productivity, a market focus, globalisation, decision-making support, and the idiosyncrasies of the industry. The core triggers for the Australian mining industry, in order of significance, were productivity, cost and process efficiency, workers' safety, and environmental sustainability. These core triggers are congruent with the South African mining industry's main challenges for which digital transformation needs to be adopted. 
Interestingly, a customer focus and value differentiation were not viewed as triggers by the Australian mining industry. That is to be expected in the mineral, mining, and metals sectors, because commodity specifications are universally standardised. For example, it is known that a gold troy ounce is equivalent to 31.1035g; and metal products are generally not differentiated as intellectual property (IP); however, they can be produced safely and cost-effectively through relevant technological initiatives.

Productivity improvement is one of the key challenges in the South African mining industry, and it is a matter of some urgency. The mining industry needs to reverse the trend of deteriorating productivity in order to deal effectively with volatile commodity prices [55], [56], [57].

The adoption of digital transformation/4IR technological initiatives to address environmental sustainability issues is pertinent for the South African mining industry as it grapples with the Decarbonisation Act and global sustainability goals. The mining industry is inherently energy-intensive. According to a study by Deloitte for Eskom, the mining industry and manufacturing jointly account for about 60 per cent of national electricity consumption, while their combined GDP contribution is about 22 per cent [58].

What becomes apparent is that none of the scholarly work that has been scrutinised has been able to classify the triggers of digital transformation into those that are for business survival (operating cost optimisation) and those that are for profitability (growth strategies). The triggers could also be classified according to the company's external environment - namely, the operating, industry, and remote environments. 'Operating environment' refers to the immediate competitive condition that will influence a company's ability to secure resources; 'industry environment' refers to the general condition that applies to all companies that provide similar products and services; and the 'remote environment' consists of factors that, by their nature, fall outside the company's operating situation, such as economic, political, social, technological, and ecological factors.

Figure 1 shows the triggers of digital transformation classified according to a company's operating environment. It can be seen that the triggers under 'remote environment' include globalisation, sustainability goals, political issues, technological change, and ecological issues. Technological change is one of the critical triggers that every company should be aware of, because technological changes will influence its industry and its performance. Other critical triggers from the remote environment are globalisation and sustainability goals.

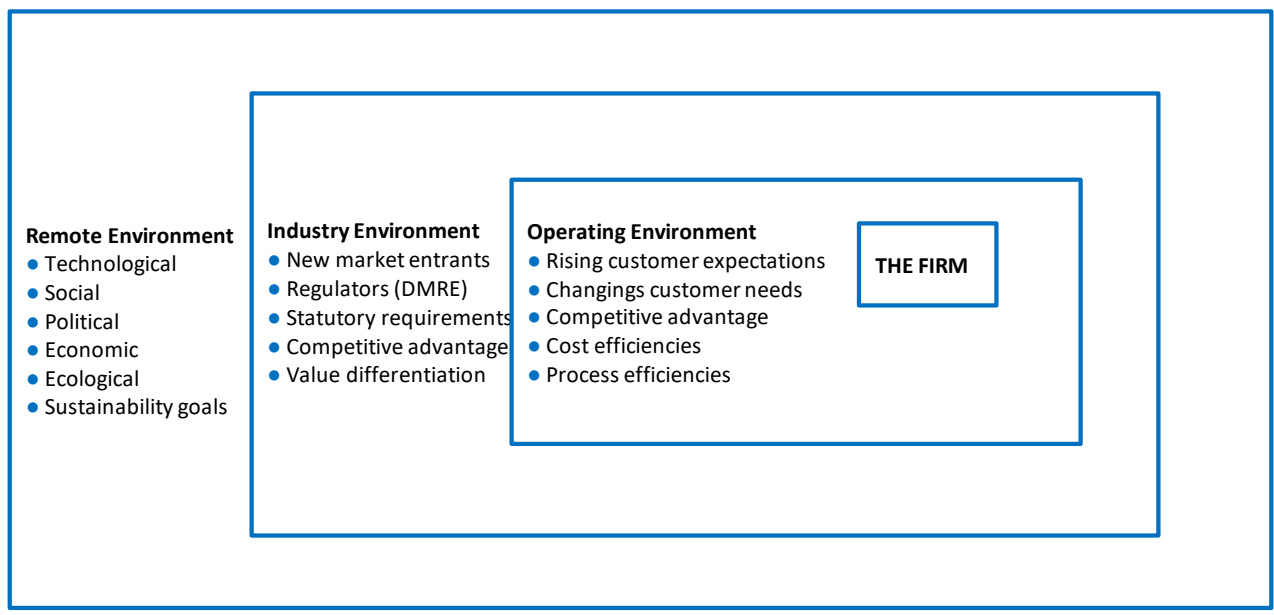

Figure 1: Triggers of digital transformation classified according to a company's external environment (based on [59]).

Under 'industry environment', the triggers are new market entrants, regulators, statutory requirements, competitive advantage, and value differentiation. New market entrants inherently disrupt industries by adopting state-of-the-art technologies that address the legacy issues of older technologies. In the case of the South African mining industry, statutory requirements and regulators (such as the Department of Minerals Resources and Energy [DMRE]) are some of the most prominent triggers of digital transformation.

The triggers of digital transformation initiatives under 'operating environment' are rising customer expectations and ever-changing customer needs, competitive advantage, cost efficiencies, and process 
efficiencies. For the South African mining industry, competitive advantage, cost, and process efficiencies are highly relevant as a result of the current major challenges. It has been noted by various researchers that, for the mining industry to be cost-effective and to achieve optimal process efficiencies, technological advances and innovation endeavours are important [55], [60].

Some researchers have identified some rather uncommon triggers for digital transformation in some companies, such as remodelling products into services (RPIS) and digital natives [61]. This refers to instances when companies develop software versions of their physical assets in order to earn application revenue. It has been asserted that that such developments typically initiate the pursuit of new business models and new revenue streams, often forced by changes in customer expectations about products and services [38]. Table 1 is a summary of the common key drivers for companies to embrace digital transformation/4IR.

Table 1: Summary of key drivers of $4 I R$

\begin{tabular}{|l|l|}
\hline Key findings/contributions & Publications \\
\hline $\begin{array}{l}\text { Customer focus and expectation/value creation/ differentiation/ } \\
\text { remodelling products into services }\end{array}$ & $\begin{array}{l}{[14],[38],[46],} \\
{[99],[54]}\end{array}$ \\
\hline Cost efficiency and process efficiency & $\begin{array}{l}{[4],[18],[44],[45],} \\
{[54]}\end{array}$ \\
\hline Safety, Health and Environment (SHE) & {$[10],[54]$} \\
\hline Productivity & {$[46],[55],[56],[57]$} \\
\hline $\begin{array}{l}\text { Market focus/globalization/new market entrants/small domestic } \\
\text { markets }\end{array}$ & {$[54],[98]$} \\
\hline Digital natives/new digital technologies & {$[42],[55],[60]$} \\
\hline Decision-making & {$[54]$} \\
\hline Others / miscellaneous & {$[54]$} \\
\hline
\end{tabular}

The triggers discussed above illustrate that the digital transformation/4IR phenomenon is key for the South African mining industry if it is to tackle its current major challenges. Digital transformation technologies form the foundation of revolutionary change in all industries. Most importantly, digital transformation has arrived, it is inevitable, and it will make a significant contribution to the prosperity of the South African mining industry.

\subsection{What are the challenges that companies encounter when adopting digital transformation?}

The digital transformation/4IR phenomenon is still emerging, with some companies having made considerable progress in its adoption and implementation, and others having not yet started; so, the challenges are likely to continue. Most important to note is that digital transformation is viewed differently by different companies, as it is a significant function of each company's vision, level of maturity, and strategic direction [62]. Thus, challenges relating to the adoption and implementation of digital transformation initiatives will manifest themselves in different forms, from obvious to subtle.

Digital transformation/4IR initiatives, like any technology project, can be implemented by following a series of steps from initiation through to monitoring. It has been posited that challenges in implementing digital transformation initiatives could occur during the initiation phase, during the executing phase, and even during the governance phase [63]. The challenges associated with the initiation phase include a lack of impetus, regulation and reputation, and an unclear business case. The challenges associated with the execution phase can include missing skills, culture issues, and IT constraints. Last, the governance-related challenges include an incremental vision and co-ordination issues.

The organisational barriers to digital transformation in companies include no sense of urgency, insufficient funding, the limitations of existing IT systems, unclear roles and responsibilities, a lack of vision, an unclear business case, the business operating in silos, its culture not being amenable to change, and regulatory 
concerns and institutional setups [14]. 'Institutional setup', in this context, refers to the attitude of older workers and to legacy technologies and innovation fatigue.

It is important to note that, when a company acquires 4IR/digital transformation technology, it will most likely be retrofitted into the existing business structure and systems. If this is not done diligently, it could lead to unexpected challenges, such as the productivity paradox and the total failure of the initiative. This point is well-corroborated: it is not only about recognising innovative technology, but also about how to integrate it into an existing business model [64].

Also important to note is that, for the smart processes to work successfully and effectively throughout the organisation's entire value chain, an all-encompassing supporting technology platform is required to ensure reliable data collection, data processing and analytics, data exchange, connection, and co-ordination [65]. This requirement leads to other challenges, such as the creation and management of big data and information, and a lack of flexibility in the existing IT infrastructure [45], [66], [98]. The implementation of digital transformation requires human resources with computational and data analytical skills. It has been postulated that big data human resources (data scientists) are scarce and difficult to find, and come at a relatively higher total cost to the company because of the novelty of the discipline [67].

The challenges discussed above are found in all industries, the mining industry included. The categories of IT/ICT-related challenges that mining companies face when implementing digital transformation initiatives include the operationalisation of a business strategy (by linking objectives with information data), change management, the effective application of technologies, and managing the external constraints [18].

It has been observed that the challenges of implementing digital transformation in the mining industry are predominantly IT/ICT-related, such as a lack of staff with digital knowledge and competencies, and digital disconnection [18]. The minerals, mining, and metals industries have been found to be characterised by a relative digital intensity index (DII) of around only 10 per cent [4]. However, the challenges highlighted by [18] are more to do with IT/ICT infrastructural constraints and abilities. It is important to note that ICT/IT is just one of the enablers of digital transformation initiatives, and is not an end in itself.

Scholarly work has been done to identify what would constitute a critical suite of challenges (grouped under themes) associated with the implementation of digital transformation/4IR in the mining industry. Aggregate themes have included a lack of the ability to change, goal ambiguity, technological constraints, and external constraints [4].

The existing scholarly work on digital transformation is silent about frameworks and guidelines for the successful implementation of digital transformation initiatives. The adoption of digital transformation/4IR technological initiatives should follow a systematic process like any technological change that would be managed in a company.

This sequence could be followed: identifying the problem, selecting the digital transformation technology, developing a solution, implementing, and monitoring. The challenges identified earlier by various authors are rather haphazard, as they do not show an appreciation of a problem-solving model in a company environment. When identifying the problems associated with the adoption of digital transformation technologies, it is important to classify them according to the stages of the problem-solving model/process.

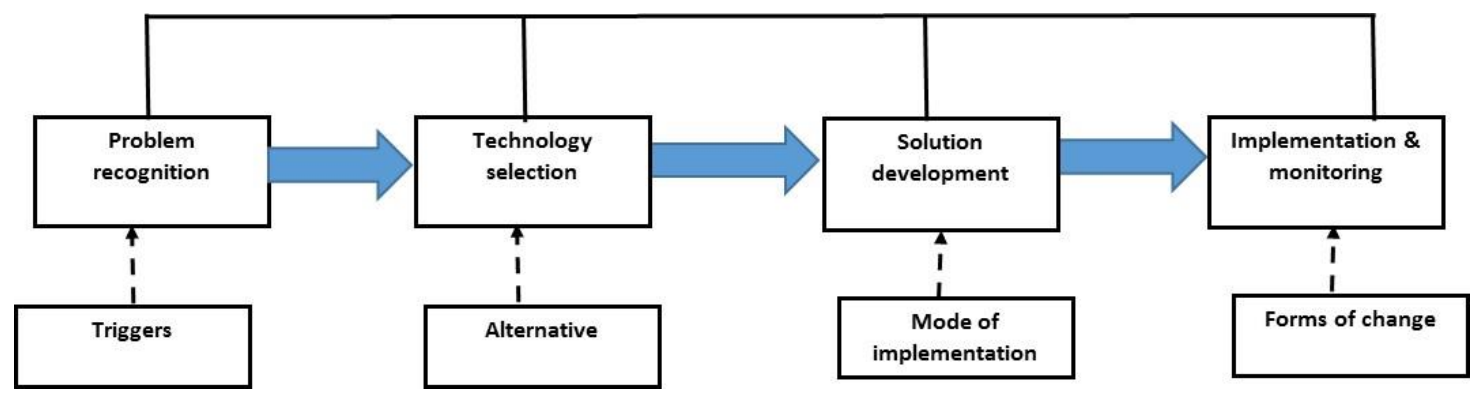

Figure 2: Technology management model for problem-solving [68]

Figure 2 shows a technology management model for problem-solving [68]. This model could be used as the basis for categorising the challenges associated with adopting digital transformation/4IR technological initiatives. It is very important to understand from which stage of the problem-solving model the problem emerges, because the challenges associated with each stage have different traits and attributes. 
For example, in the problem-recognition phase, challenges could result from not understanding the triggers of the problem, and could include factors such as technological feasibility, market potential (for products and services), and mandatory/regulatory constraints; in the technology-selection phase, the challenges could be associated more with designs and technology choices; in the solution-development stage, the challenges could be associated with innovation and adoption; and in the implementation-and-monitoring stage, the challenges would be more about reconfiguring the value chains and commercialising new products and services.

The above elaborations are an indication that the adoption of digital transformation is a complex process, and brings with many challenges. What makes it particularly complex is that it involves combinational technologies, and diminishes the conventional boundaries between technologies and disciplines.

It is also apparent that the challenges associated with adopting and implementing digital transformation technological initiatives in the mining industry are still being identified and characterised, and not all of them are easy to identify. They are not only about the acquisition of digital transformation technology, but are also dispersed across the problem-solving model, from problem identification through to implementation.

With the advent of the 4IR era, technology managers face a relatively high level of uncertainty about the needs and expectations of customers with respect to products and services; hence the need for industries to supplement it with creativity and well-thought-out and flexible new business models. Table 2 summarises the common challenges that companies face in implementing digital transformation/4IR technological initiatives.

Table 2: Key challenges for digital transformation/4IR implementation

\begin{tabular}{|l|l|}
\hline Key findings/contributions & Publications \\
\hline Implementation and application/ operationalisation of business strategy & {$[18],[63],[64],[98]$} \\
\hline Organisational barriers (no sense of urgency, lack of funding, unclear role and responsibilities) & {$[14],[62],[70]$} \\
\hline IT/ICT infrastructural constraints/skills & {$[18],[58],[65],[66]$} \\
\hline Data management & {$[45],[65],[67]$} \\
\hline Technological constraints & {$[4],[66]$} \\
\hline External constraints/regulatory constraints & {$[4]$} \\
\hline Lack of leadership and culture & {$[4],[62],[98]$} \\
\hline Cyber-security & {$[63],[70]$} \\
\hline Change management & {$[58]$} \\
\hline
\end{tabular}

\subsection{What are the general success factors for digital transformation/4IR implementation?}

Many authors have dealt with the subject of the success factors and success dimensions in adopting digital transformation/4IR technological initiatives in various companies and industries. So far, the predominant perspectives have included organisational and customer issues [69], integrating digital and physical components [98], leadership capabilities [70], [64], [71], digital strategy [72], awareness and training [44], cultural change [66], creating a digital enterprise vision and matching operational goals [73], reviewing existing business models [62], creating innovative ideas that link across the boundaries of the company [98], a supportive and agile organisational culture [52], and developing a framework [74].

It should also be highlighted that some authors, such as [74] and [75], have attempted - incorrectly - to study the success factors in adopting digital transformation by approaching the topic purely in the context of the discipline of IT/ICT. But, as noted earlier, IT/ICT is just one of the enablers of the adoption of digital transformation, and is not an end in itself.

The literature presents the success factors of the digital transformation phenomenon as a multi-dimensional construct. This study is interested in further understanding the following:

- What is 'success' in the context/theme of digital transformation/4IR technologies?

- How is the success of digital transformation/4IR technological initiatives measured?

There is much divergence over measuring success in the context of digital transformation because, to some extent, the digital transformation literature is still emerging. An appropriate success dimension to be 
measured will also depend on the triggers and objectives of adopting digital transformation technological initiatives by a company.

When a company adopts digital transformation technologies, it should create an additional value (such as market capitalisation and price/book value multiples) for the company. Authors such as [76] and [53] have considered company value to be one of the critical dimensions in measuring the success of digital transformation.

The analysis of the success of digital transformation technological initiatives has also been based on operational efficiency and profitability, measured in earnings per share, operating profit margin, and return on asset. These success dimensions analyse a company's ability to generate income, to manage and control its costs effectively (cost-effectiveness), and to generate acceptable profit margins.

For the South African mining industry, the success of digital transformation technological initiatives can be measured against the success dimensions relating to the major challenges - namely, improved safety (measured by a decline in fatalities, a reduced rate of time lost through injury, reduced DMRE Section 54s stoppages, productivity (measured by enhanced revenue, increased throughput, increased equipment uptime and utilisation), reduced operating costs (measured by a higher productivity of equipment, improved and reduced labour and consumables costs, an improved operating profit, reduced waste generation, such as over-stripping waste), a reduced capital intensity (measured by a reduction in damage to equipment and failures owing to poor asset management), and the improved life of the mine and its reserves (measured by better and more reliable exploration data, the feasibility of deep-level mining where it would not be possible for people to work because of heat stress levels and other geological constraints).

Another important success dimension that the mining industry can realise from the implementation of digital transformation technological initiatives is the end-to-end productivity gains that are manifested in features such as integration across all the elements of the mineral, mining, and metals value chains, visibility across the value chain, the availability of complex but reliable decision support, integrated production, quality management, and asset management.

Some authors have focused on the sales and customer-base dimensions as measures of the success of digital transformation technological initiatives [77], [78], [79], [80], [81], [82], [83]. This success dimension is applicable to service providers such as insurance brokers and banks. Other success dimensions for service providers are company reputation and customer satisfaction [79], [84], [85].

Digital transformation initiatives can also be acquired purely for the purpose of addressing the ergonomic challenges that the workforce experiences in the workplace. Thus one of the success dimensions for digital transformation technological initiatives is workplace quality and safety, which can be measured by the turnover in workers, worker satisfaction, and other employee-performance dimensions.

Interestingly, no scholarly work appears to consider the success of digital transformation initiatives in terms of general project evaluation protocols - i.e., costs, schedules, and deliverables. The adoption of a digital transformation initiative is so large and complicated that it warrants a full project management approach. In that case, additional elements arise that could cause the failure of a technological initiative, such as an inappropriate project management approach, an inexperienced project manager, and incorrect scheduling of resources.

The readiness and the ability to manage are other success factors in the adoption of digital transformation that have been overlooked by many authors. It has been asserted by some that managers are key to determining a company's performance outcomes [86], [87], [88], [89], [90]. Table 3 shows the key success factors in a successful digital transformation/4IR implementation.

\subsection{What are the existing approaches to leading digital transformation initiatives?}

As part of this study, an attempt was made to determine why companies adopt and implement digital transformation technological initiatives and challenges; general success factors were also discussed.

It is apparent from the above discussions that, by definition, the implementation of digital transformation/4IR technological initiatives is relatively more complicated than in the previous industrial revolutions. Thus, it is important to understand the existing approaches to the adoption and implementation of digital transformation/4IR technological initiatives. 
Table 3: Key success factors for digital transformation/4IR implementation

\begin{tabular}{|l|l|}
\hline Key findings/ contributions & Publications \\
\hline People/awareness and training/skills & {$[44],[73]$} \\
\hline Organisational culture/leadership capabilities & {$[64],[69],[70],[71],[73],[98]$} \\
\hline Technological framework/institutional framework & {$[48],[73],[74]$} \\
\hline Clear business goals (business value/performance/ sustainability/satisfaction) & {$[64],[70],[71]$} \\
\hline Digital strategy & {$[41],[72]$} \\
\hline Value creation/appropriation & {$[48],[73],[74]$} \\
\hline Integration & {$[20]$} \\
\hline Levels of impact/adoption & {$[20]$} \\
\hline Alignment of relevant stakeholders (employees, customers, suppliers etc.) & {$[20]$} \\
\hline
\end{tabular}

What makes digital transformation a particularly complex phenomenon is the fusion of industrial production, people, and ICT. It is the only phenomenon that has made it possible to connect information, machines, and people because of the combining of physical space and cyberspace into cyber-physical systems [20], [38], [91].

The adoption of digital transformation involves numerous synergies among various technologies from various disciplines. Thus, for companies to adopt and implement digital transformation initiatives successfully, they need to redefine their technology management strategies, as they have to retrofit smart processes into their entire value chain systems.

The implementation of digital transformation technological initiatives needs to be aligned with the company's technology strategy, which is a function of various factors such as technology evolution, industry context, strategic action, and organisational context.

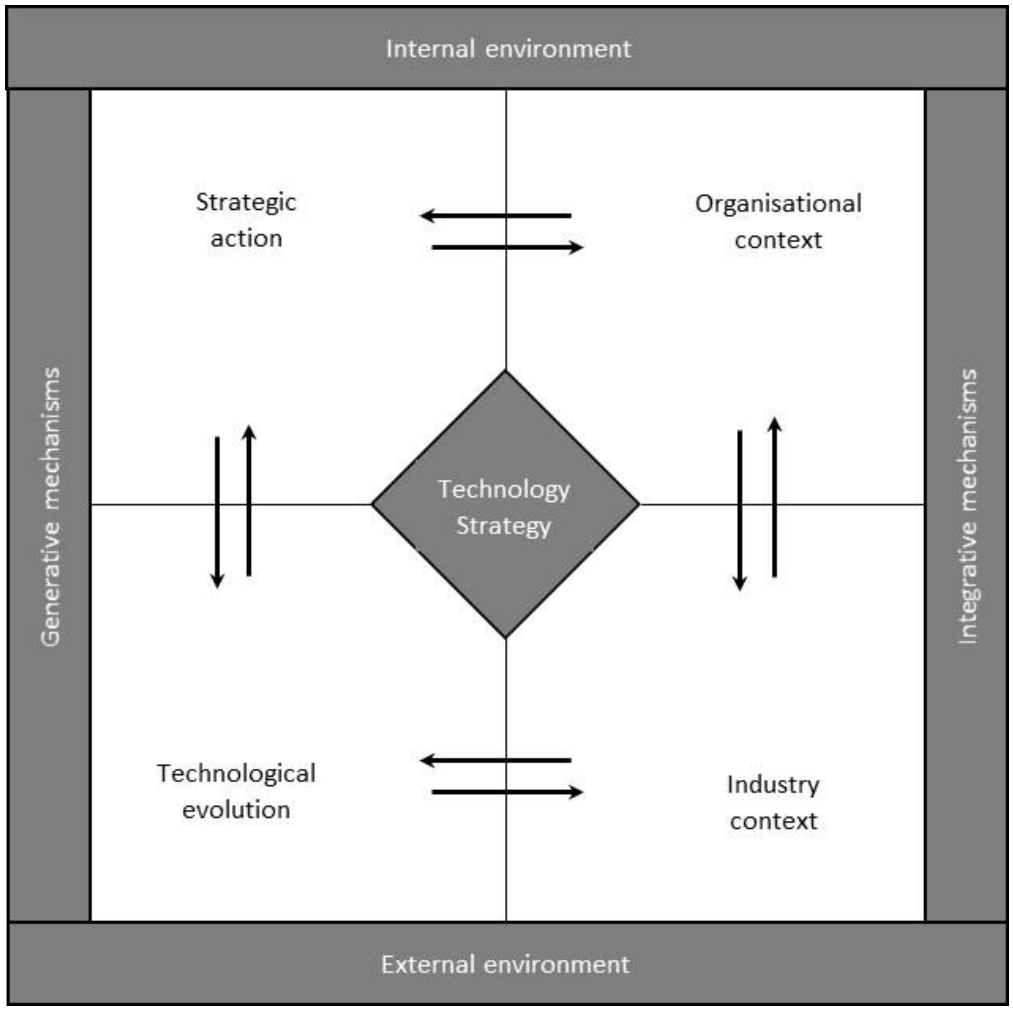

Figure 3: Some factors influencing the adoption and implementation of technological projects [92)

Figure 3 shows the conceptual framework that illustrates the evolutionary forces that shape and influence the selection and implementation of technology projects. Implementing digital transformation/4IR technologies in the South African mining industry is no exception. Thus the implementation of digital transformation technologies will be influenced by the company's internal and external environments alike. 
Another popular approach to digital transformation/4IR is Reference Architecture Model Industry 4.0 (RAMI 4.0), developed by BITCOM, VDMA, and ZWEI. RAMI 4.0 is a three-dimensional map that shows how to approach 4IR in a structured manner [93], [94], [95], [96], [97].

Figure 4 shows that the development of RAMI 4.0 focused on industrial production as the primary area of application, including discrete manufacturing in process industries. The right-hand horizontal axes are the hierarchy levels from IEC 62264, the international standards series for enterprise IT and control systems, representing the different functionalities in factories or facilities. The left-hand horizontal axes represent the life cycle of facilities and products, based on IEC 62890, the life-cycle management for systems and products that is used in industrial-process measurement, control, and automation. The six layers on the vertical axis describe the decomposition of a machine into its properties, structured layer-by-layer - i.e., the virtual mapping of a machine.

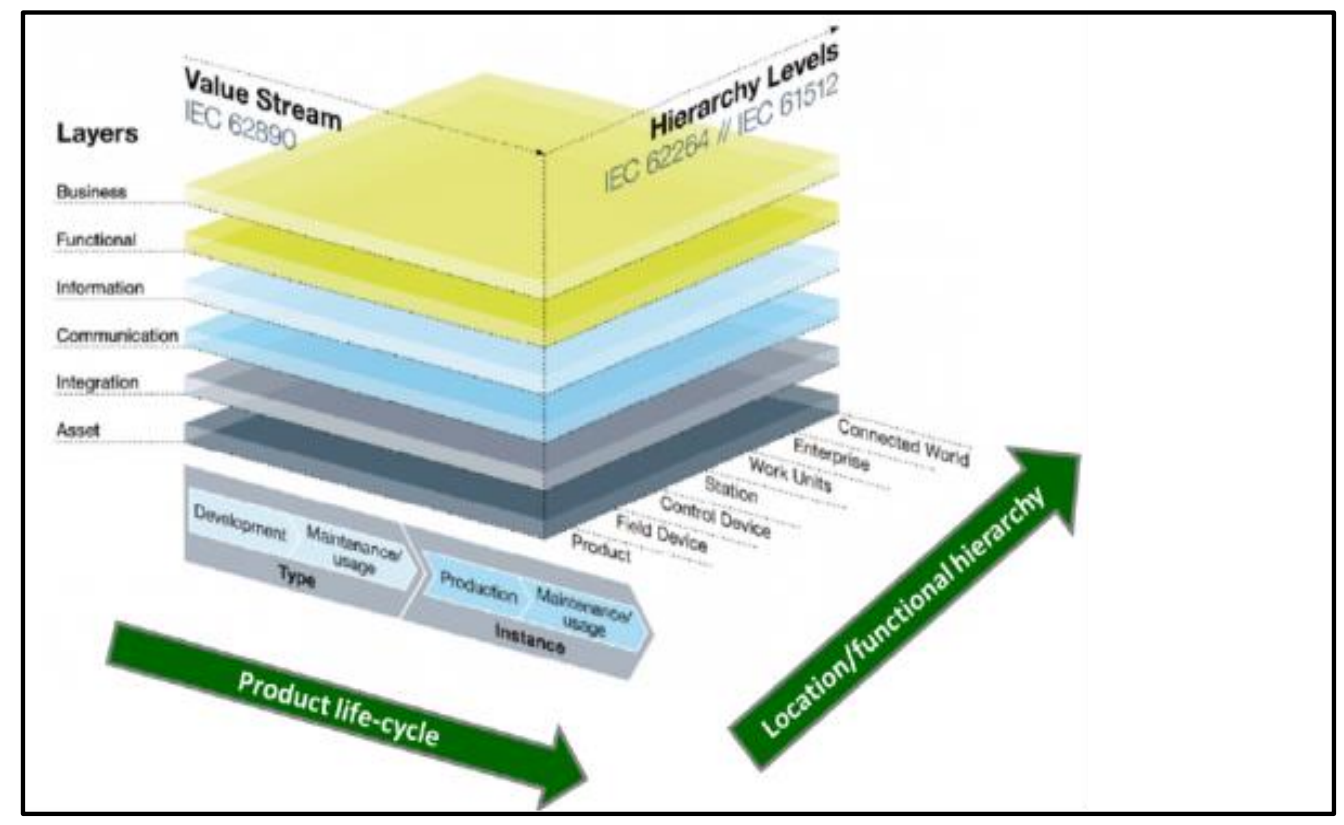

Figure 4: The RAMI 4.0 model [97]

RAMI 4.0 focuses mainly on the definition of rules for the implementation of digital transformation/4IR from a strategic point of view. It ensures that all of the complex processes of implementing digital transformation are broken down into easy-to-understand steps and packages.

Another approach to implementing digital transformation is the Reference Model for Industry 4.0 Service Architecture (RM-SA). This provides an implementation guideline for technology-independent services in the communication, information, and functional layers of RAMI 4.0 to ensure full interoperability between 4IR components.

The 4IR concepts are being applied to process industries to achieve a holistic integration of the automation, business information, and manufacturing execution functions to improve all aspects of production and commerce across process industries' value chains for greater efficiency. The adoption of the 4IR phenomenon involves numerous synergies among various technologies from various suppliers. The successful implementation of 4IR compels the companies implementing it to redefine their technology management strategies, as they have to retrofit smart processes into their entire value chain system.

In addition, for the smart process to work successfully and effectively through the entire value chain, a comprehensive supporting technology platform is required that will ensure reliable data collection, data processing and analytics, data exchange, connection, and co-ordination [98]. This is called the 4IR general adaptation framework, which is one of the key approaches to implementing digital transformation.

Consideration of the organisational context is important for the successful adoption of 4IR/ digital transformation technologies, as it affords the company an opportunity to select an appropriate route for its digital transformation journey. This is particularly important, as the challenges and opportunities 
brought about by the advent of digital transformation/4IR may emerge spontaneously outside the perimeter of existing company strategy.

Companies can also approach the adoption of digital transformation technological projects by following the general technology management approach, which entails a diagnosis and an understanding of the environmental context of the company's strategic position, a commitment of resources to digital technological projects, and a mode of implementation and organisation to execute the digital transformation initiatives.

In conclusion, it can be seen that there is a need for frameworks and guidelines for the successful adoption and implementation of 4IR technological initiatives.

\section{CONCLUSIONS AND RECOMMENDATIONS}

From the above discussions, it can be concluded that the influence and impact of digital transformation/4IR is wide-ranging, and that it will affect all industries and every human life. All companies must consider themselves relatively vulnerable to digital transformation technologies, and should strategise intensively to embrace them. Given that the South African mining industry is one of the key industries for its socioeconomic contribution (employment, technological development, economic stability), it has to take a prominent role in the adoption and implementation of 4IR/digital transformation.

The digital transformation in South African mining presents an opportunity to address its current major challenges, such as high operating costs and relatively low profitability, safety and health issues, and regulatory imperatives. It also gives the South African mining industry a strong mandate to face its global competitors boldly and aggressively.

The Minerals Council of South Africa has defined 4IR as technological developments that blur the lines between the physical, digital, and biological spheres. It essentially integrates cyber-physical systems and the Internet of Things, big data, cloud computing, robotics, artificial intelligence-based systems, and additive manufacturing. Thus there is a notable synergy and convergence among different technologies, whether physical, digital, or biological.

The rate of digital transformation/4IR in the mining industry is still relatively low, and most mining companies have not been successful in implementing it. There are various reasons why companies adopt digital transformation: some are purely operational, and some are simply to achieve company-wide strategies. The common triggers of digital transformation include improving quality management processes, maximising production, improving working conditions in respect of safety and health, and ensuring quality products and customer satisfaction.

Since digital transformation is an emerging phenomenon, companies encounter a lot of challenges, and some of them lead to the failure of the implementation. The common challenges faced by companies when adopting digital transformation relate to technology management, external constraints, change management, IT/ICT infrastructure, leadership, and organisational constraints and capabilities.

The success factors identified in this article include the integration of physical and digital components, leadership capabilities, a digital strategy, a review of existing business models, supportive and agile organisational structures, and robust technology frameworks. However, there is a lot divergence over how to measure success in the context of digital transformation - probably owing to the complex nature of digital transformation and its novelty.

Existing approaches to the implementation of digital transformation/4IR include the Reference Architecture Model Industry 4.0 (RAMI 4.0), which is a three-dimensional model that represents all of the different interconnected features of a company's operation. The RAMI 4.0 model ensures that all of the stakeholders involved in the 4IR endeavour understand one another. Most importantly, there is a 4IR/digital transformation adaptation framework, which is characterised by its communicating and networking aspects (data collection, data processing, data analytics, and intelligent data management). There are also supporting technologies such as cloud systems, sensors and actuators, virtualisation technologies, and adaptive robotics.

From the integrative review of the literature conducted in this study, it can be concluded that, when companies adopt digital transformation/4IR technological initiatives, they give themselves an opportunity to improve their competitive positions, increase value creation, and improve risk management, because of 
the more efficient and faster production systems and innovative technology. However, the adoption of digital transformation is a complex process that brings many challenges. What makes it particularly complex is that it involves combinational technologies and diminishes the boundaries between technologies and disciplines.

Future research could focus on developing frameworks and guidelines for adopting and implementing digital transformation/4IR technological initiatives in the mining industry.

\section{REFERENCES}

[1] J. Potts, M. Wenban-Smith, L. Turley, and M. Lynch, State of sustainability initiative review: Standards and the extractive economy. Winnipeg, Manitoba, Canada, International Institute for Sustainable Development, 2018.

[2] S.Gao, E. Hakanen, and R. Rajala, "Digital transformation: The interplay of explorative and exploitative capability development," Paper presented at Annual Hawaii International Conference on System Sciences, Maui, United States, pp. 4306-4315, 2020.

[3] A. Rojko, "Industry 4.0 concept: Background and overview," International Journal of Interactive Mobile Technologies, Vol. 11 No. 5, pp. 77-90, 2017.

[4] S.Gao, E. Hakanen, P. Töytäri, and R. Rajala, "Digital transformation in asset-intensive businesses: Lessons learned from the metals and mining industry," Hawaii International Conference on System Science (HICSS), Wailea, HI, 2019.

[5] Minerals Council of South Africa. Facts and figures 2018-2019. Minerals Council of South Africa (MCSA), Johannesburg, South Africa, 2019.

[6] C. Middel, "Why digital transformation is not the silver bullet that many are expecting. How to make it work for you," In: The Southern Africa Institute of Mining and Metallurgy, Digitalization in Mining Conference, Webinar, July 2020.

[7] M. Reeves, L. Fæste, K. Whitaker, and F. Hassan, "The truth about corporate transformation", MIT Sloan Management Review, January 31, 2018. [Online]. Available: https://sloanreview.mit.edu/article/the-truth-aboutcorporate-transformation/. [Accessed June, 23, 2021].

[8] F. Li, "Leading digital transformation: Three emerging approaches for managing the transition," International Journal of Operations \& Production Management, Vol. 40, No.6, 2020, pp.809-817.

[9] H. Snyder, "Literature review as a research methodology: An overview and guidelines," Journal of Business Research, Vol. 104, pp. 333-339, 2019.

[10] R.J. Torraco, “Writing integrative literature reviews: Guidelines and examples," Human Resources Development Review, Vol. 4, pp. 356-367, 2005.

[11] M.W. Covington, "Goal theory, motivation, and school achievement: An integrative review," Annual Review of Psychology, Vol. 51, pp. 171-200, 2000.

[12] J.J. Gross, “The emerging field of emotion regulation: An integrative review," Review of General Psychology, Vol. 2, pp. 271-299, 1998.

[13] T. Mazinder, S.P. Raj, and I. Sinha, "Reference price research: Review and positions," Journal of Marketing, Vol. 69, pp. 84-102, 2005.

[14] M. Fitzgerald, N. Kruschwitz, D. Bonnet, and M. Welch, “Embracing digital technology," Research Report, MIT Sloan Management Review, 2013.

[15] M. Lee, J.J. Yun, A. Pyka, D. Won, F. Kodama, G. Schiuma, H. Park, J. Jeon, K. Park, K. Jung, M. Yan, S. Lee, and $X$. Zhao, "How to respond to the Fourth Industrial Revolution, or the Second Information Technology Revolution? Dynamic new combinations between technology, market, and society through open innovation," Journal of Open Innovation, Technology, Market and Complexity, Vol. 4 No. 21, pp. 1-24, 2018.

[16] A.C. Pereira and F. Romeo, "A review of the meanings and implications of the Industry 4.0 concept," Procedia Manufacturing, Vol. 13, pp. 1206-1214, 2017.

[17] S. van der Woude, Challenges in mining for the Fourth Industrial Revolution, Mineral Council of South Africa, 2019.

[18] Z. Dragicevic and S. Bosnjak, "Digital transformation in the mining enterprise: The empirical study," Mining and Metallurgy Institute BOR, Vol. 1-2, pp. 73-90, 2019.

[19] K. Schwab, The Fourth Industrial Revolution: What it means and how to respond, 2015. [Online]. Available: https://www.weforum.org/agenda/2016/01/the-fourth-industrial-revolution-what-it-means-and-how-torespond/. [Accsssed May, 12, 2021].

[20] H. Kagermann, W. Wahlster, and I. Helbig, Recommendations for implementing the strategic initiatives Industry 4.0, Acatech - National Academy of Science and Engineering, 2013.

[21] P.C. Evansand and A. Gawer, The rise of the platform enterprise: A global survey. 2016, The Centre for Global Enterprise. [Online]. Available: https://openresearch.surrey.ac.uk/esploro/outputs/report/The-Rise-ofthe-Platform-Enterprise-A-Global-Survey/99516671002346. [Accessed May, 23, 2021].

[22] D. Ness, J. Swift, D.C. Ranasinghe, K. Xing, and V. Soebarto, "Smart steel: New paradigms for the reuse of steel enabled by digital tracking and modelling," Journal of Cleaner Production, Vol. 98, pp. 292-303, 2015.

[23] R. Rajala, E. Hakanen, T. Seppälä, J. Mattila, and M. Westerlund, "How do intelligent goods shape closed-loop systems?”, California Management Review, Vol. 60 No. 3, pp. 20-44, 2018.

[24] M. Porter and J. Heppelmann, "How smart, connected products are transforming competition," Harvard Business Review, Issue 3, pp. 64-88, 2014.

[25] G. Kube and T. Rinn, "Industry 4.0: The next revolution in the industrial sector," ZGK International, Vol. 68 No. 11, pp. 30-32, 2014 
[26] D. Schallmo, C. A. Williams, and L. Boardman, "Digital transformation of business models - best practice, enablers, and roadmap," International Journal of Innovation Management, Vol. 21, no. 8.pp: 1-17, 2017.

[27] M. Xu, J.M. David, and S.H. Kim, “The Fourth Industrial Revolution: Opportunities and challenges," International Journal of Financial Research, Vol. 9 No.2, pp. 90-95, 2018.

[28] F. Zezulka, P. Marcon, I. Vesely, and O. Sajdl, “Industry 4.0: An introduction in the phenomenon," International Federation of Automatic Control, Vol. 49 No. 25, pp. 008-012, 2016.

[29] J. Manyika, M. Chui, B. Brown, J. Bughin, R. Dobbs, C. Roxburgh, and A. Hung Beyers, Harnessing automation for a future that works. Report by McKinsey Global Institute, 2017.

[30] Y. Wang, G. Wang, and R. Anderl, "Generic procedure model to introduce Industrie 4.0 in small and medium size enterprises," In Proceedings of the World Congress on Engineering and Computer Science, pp. 971-976, 2016.

[31] A.G. Frank, L.S. Dalenogareb, and N.F. Ayala, “Industry 4.0 technologies: Implementation patterns in manufacturing companies," International Journal of Production Economics, Vol. 210, pp 15-26, 2019.

[32] T.S. Ing, T.C. Lee, S.W. Chan, J. Alipal, and N.A. Hamid, "An overview of the rising challenges in implementing Industry 4.0," International Journal of Supply Chain Management, Vol. 8 No. 6, pp. 1181-1188, 2019.

[33] B. Kamp and G. Parry, "Servitization and advanced business services as levers for competitiveness," Industrial Marketing Management, Vol. 60, pp. 11-16, 2017.

[34] L. Monostori, B. Kádár, and T. Bauernhansl, "Cyber-physical systems in manufacturing," CIRP Annals Manufacturing Technology, Vol. 65 No. 2, pp. 621-641, 2016.

[35] B. Eaton, S. Elaluf-Calderwood, C. Sørensen, and Y. Yoo, "Distributed tuning of boundary resources: The case of Apple's iOS service system,” MIS Quarterly, Vol. 39 No. 1, pp. 217-243, 2015.

[36] C. Arnold, D. Kiel, and K.I. Voigt, "Innovative business models for the Industrial Internet of Things," BHM-und Huttenmannische Monatshefte, Vol. 169 No. 9, pp. 371-381, 2017.

[37] W.H. Bauer, M. Schlund, and C. Vocke. "Transforming to a hyper-connected society and economy: Towards an Industry 4.0," Procedia Manufacturing, Vol. 3, pp. 417-424, 2015.

[38] D. Ibarra, J. Ganzarain, and J.I. Igarta, "Business model innovation through Industry 4.0: A review," International Conference on Interdisciplinarity in Engineering, Tirgu Mures, Romania, pp. 4-10, 2017.

[39] A.S. Bharadwaj, "A resource-based perspective on information technology capability and firm performance: An empirical investigation," MIS Quarterly, Vol. 24 No. 1, pp. 169-96, 2000.

[40] M.H. Shah and F.A. Siddiqui, "Organizational critical success factors in adoption of e-banking at the Woolwich Bank," International Journal of Information Management, Vol. 26 No. 6, pp. 442-56, 2006.

[41] D.Y. Liu, S.W. Chen, and T.C. Chou, "Resource fit in digital transformation: Lessons learned from the CBC Bank global e-banking project," Management Decision, Vol. 49 No.10, pp. 1728-1742, 2011.

[42] C. Matt, T. Hess, and A. Benlian, "Digital transformation strategies," Business \& Information Systems Engineering, Vol. 57 No. 5, pp. 339-343, 2015.

[43] B.R. Haverkort and A. Zimmermann, "Smart industry: How ICT will change the game!", IEEE Internet Computing, Vol. 21 No. 1, pp. 8-10, 2017.

[44] J.S. de Sousa, I.O. Rocha, and R.M. de Castro, "Digital transformation applied to Bauxite and Alumina Business System: BABS 4.0," in Proceedings of 37th International ICSOBA Conference, pp. 119-132, 2016.

[45] A. De Carolis, M. Macchi, E. Negri, and S. Terzi, "Guiding manufacturing companies towards digitalization: A methodology for supporting manufacturing companies in defining their digitalization roadmap," in International Conference on Engineering, Technology and Innovation (ICE/ITMC), pp. 487-495, 2017.

[46] I. Haffke, B. Kalgovas, and A. Benlian, "The role of the CIO and the CDO in an organization's digital transformation," in ICIS 2016 Proceedings, pp. 1-20, 2016.

[47] J. Schmidt, P. Drews, and I. Schirmer, "Digitalization of the banking industry: A multiple stakeholder analysis on strategic alignment," Twenty-third Americas Conference on Information Systems, Boston, MA, USA, 2017.

[48] S. Berghaus and A. Back, "Stages in digital business transformation: Results of an empirical maturity study," In Proceedings of the Tenth Mediterranean Conference on Information Systems (MCIS), pp. 1-17, 2016.

[49] D. Bilgeri, F. Wortmann, and E. Fleisch, "How digital transformation affects large manufacturing companies' organization," in ICIS 2017 Proceedings, pp. 1-9, 2017.

[50] V. Isaksson and L. Hylving, "The effect of anarchistic actions in digital product innovation networks: The case of 'over the air' software updates," in 50th Hawaii International Conference on System Sciences, pp. 5763-5772, 2017.

[51] M. Mocker and N.O. Fonstad, “Driving digitization at Audi," in ICIS 2017 Proceedings, pp. 1-15, 2017.

[52] K. Osmundsen, J. Iden, and B. Bygstad, "Digital transformation: Drivers, success factors and implications," in Proceedings of the 12th Mediterranean Conference on Information Systems (MCIS), pp. 1-5, 2018.

[53] A. Hanelt, S. Firk, B. Hildebrandt, and L.M. Kolbe, "Digital M\&A, digital innovation, and firm performance: An empirical investigation," European Journal of Information Systems, pp. 1-24, 2020.

[54] T. Lammers, L. Tomidei, and A. Regattieri, "What causes companies to transform digital? An overview of drivers for Australian key industries," Portland International Conference on Management of Engineering and Technology, Honolulu, HI, USA , 2015.

[55] C. Dodd, "Is there a future boom amongst the gloom?" AusIMM Bulletin, pp. 16-19, 2016.

[56] J. Deverell, “Unlocking future innovation in mining," AusIMM Bulletin, pp. 44-46, 2016.

[57] M. Catchpole and W. Robins, "The productivity challenge," AusIMM Bulletin, pp. 28-30, 2015.

[58] Deloitte. Tracking the trends 2018: The top 10 issues shaping mining in the year ahead. 2018. [Online]. Available: https://www2.deloitte.com/content/dam/Deloitte/us/Documents/energy-resources/us-er-ttt-report-2018.pdf

[59] J.A. Pearce II and R.B. Robinson Jr., Strategic management: Formulation, implementation and control, $10^{\text {th }}$ ed., New York, McGraw-Hill Irwin, 2007.

[60] E. Mosconi, K. Crownston, and J.V. Nickerson, "Developing skills to work in the age of intelligent machines: PreHICSS workshop," 52nd Hawaii International Conference on System Sciences (HICSS), Wailea, HI, 2019. 
[61] A.-M. Schaller, A.-A. Schaller, and R. Vatananan-Thesenvitz, "What are the general mechanism that pushes a company to transform digitally?", Institute for Knowledge and Innovation-South East Asia (IKI-SEA), Bangkok University, Thailand, 2020.

[62] S.S. Nahrkhalaji, S. Shafiee, M. Shafiee, and L. Hvam, "Challenges of digital transformation: The case of the nonprofit sector," in 2018 IEEE International Conference on Industrial Engineering and Engineering Management (IEEM), pp. 1245-1249, 2018.

[63] MIT Center for Digital Business and Capgemini Consulting, “Digital transformation: A roadmap for billion-dollar organizations," Research Report, 2011. [Online]. Available: https://www.capgemini.com/wpcontent/uploads/2017/07/Digital_Transformation_A_Road-Map_for_Billion-Dollar_Organizations.pdf.

[64] S. Earley, "The digital transformation: Staying competitive," IT Professional, Vol. 16 No. 2, pp. 58-60, 2014.

[65] P.A. Sarvari, A. Ustundag, E. Cevikcan, I. Kaya, and S. Cebi, "Technology roadmap for Industry 4.0," in Industry 4.0: Managing The Digital Transformation, Springer Series in Advanced Manufacturing, Cham, Springer, 2018.

[66] J. Erjavec, A. Manfreda, J. Jaklič, M.I. Štemberger, P. Fehér, Z. Szabó, and W.A. Kó, “Case studies of successful digital transformation in Slovenia and Hungary," 5th International Conference on Management and Organization, pp. 1-11, 2018.

[67] T.H. Davenport and D.J. Patil, "Data scientist: The sexiest job of the 21st century: Meet the people who coax treasure out of messy, unstructured data," Harvard Business Review, Vol. 9, pp. 70-77, 2012.

[68] V.K. Narayanan, Managing technology and innovation for competitve advantage, Prentice-Hall, New Jersey 2001.

[69] N. Sahu, H. Deng, and A. Molla, "A capability based framework for customer experience focused digital transformation," Australasian Conference on Information Systems, Sydney, 2018.

[70] G. Westerman, D. Bonnet, and A. McAfee, Leading digital: Turning technology into business transformation, Boston, Harvard Business Review Press, 2014.

[71] S. Khan, "Leadership in the digital age - A study on the effects of digitalization on top management leadership," Masters Thesis, Stockholm University, 2016.

[72] I. Sebastian, J. Ross, C. Beath, M. Mocker, K. Moloney, and N. Fonstad, "How big old companies navigate digital transformation," MIS Quarterly Executive, pp. 197-213, 2017.

[73] C. Klötzer and A. Pflaum, "Toward the development of a maturity model for digitalization within the manufacturing industry's supply chain," in Proceedings of the 50th Hawaii International Conference on System Sciences, pp. 42104219, 2017.

[74] K. Liere-Netheler, K. Vogelsang, S. Packmohr, and U.A. Hoppe, "Towards a framework for digital transformation success in manufacturing," in Proceedings of the 26th European Conference on Information Systems (ECIS), pp. 119, 2018.

[75] P. Barthel, "What is meant by digital transformation success? Investigating the notion in IS literature," 16 th International Conference on Wirtschaftsinformatik, Essen, Germany, March 2021.

[76] A. Moker, P. Brosi, and I. Welpe, "It depends on the size: How firm strategic emphasis on digital transformation predicts market capitalization," in Proceedings of the 53rd Hawaii International Conference on System Sciences (HICSS), pp. 5472-5481, 2020.

[77] T. Hess, C. Matt, A. Benlian, and F. Wiesböck, “Options for formulating a digital transformation strategy," MIS Quarterly Executive, Vol. 15, pp. 125-139, 2016.

[78] J.J. Ferreira, C.I. Fernandes, and F.A. Ferreira, "To be or not to be digital, that is the question: Firm innovation and performance," Journal of Business Research, Vol. 101, pp. 583-590, 2019.

[79] S. Khin and T.C. Ho, "Digital technology, digital capability and organizational performance," International Journal of Innovation Science, Vol. 11, pp. 177-195, 2019.

[80] J. Huang, O. Henfridsson, M.J. Liu, and S. Newell, "Growing on steroids: Rapidly scaling the user base of digital ventures through digital innovation," MIS Quarterly, Vol. 41, pp. 301-314, 2017.

[81] A. Leischnig, S. Wölfl, B. Ivens, and D. Hein, "From digital business strategy to market performance: Insights into key concepts and processes," in Proceedings of the 38th International Conference on Information Systems (ICIS), pp. 1-16, 2017.

[82] J.K. Nwankpa and Y. Roumani, “IT capability and digital transformation: A firm performance perspective," in Proceedings of the 37th International Conference on Information Systems (ICIS), pp. 1-16, 2016.

[83] J.K. Nwankpa and P. Datta, "Balancing exploration and exploitation of IT resources: The influence of digital business intensity on perceived organizational performance," European Journal of Information Systems, Vol. 26, pp. 469-488, 2017.

[84] R. Hansen and S.K. Sia, “Hummel's digital transformation toward omnichannel retailing: Key lessons learned," MIS Quarterly Executive, Vol. 14, pp. 51-66, 2015.

[85] J. Ryan, B. Doster, S. Daily, and C. Lewis, "Targeting perioperative performance aligned to hospital strategy via DT," in Proceedings of the 53rd Hawaii International Conference on System Sciences (HICSS), pp. 3628-3637, 2020.

[86] H.C. Lucas Jr and J.M. Goh, “Disruptive technology: How Kodak missed the digital photography revolution," Journal of Strategic Information Systems, Vol. 18, pp. 46-55, 2009.

[87] T.R. Holcomb, M.R. Holmes Jr, and B.L. Connelly, "Making the most of what you have: Managerial ability as a source of resource value creation," Strategic Management Journal, Vol. 30 No. 5, pp. 457-485, 2008.

[88] R.P. Castanias and C.E. Helfat, "The managerial rents model: Theory and empirical analysis," Journal of Management, Vol. 27 No. 6, pp. 661-678, 2001.

[89] K.A. Bantel and S.E. Jackson, "Top management and innovations in banking - Does the composition of the top team make a difference?”, Strategic Management Journal, Vol. 10, pp. 107-124, 1989.

[90] D.C. Hambrick and P.A. Mason, "Upper echelons: The organization as a reflection of its top managers," The Academy of Management Review, Vol. 9 No. 2, pp. 193-206, 1984.

[91] K.D.W. Thoben and T. Wuest, "Industrie 4.0 and smart manufacturing: A review of research issues and application examples," International Journal of Automation Technology, Vol. 11 No. 1, pp. 4-16, 2017. 
[92] R.A. Burgelman and R.S. Rosenbloom, “Technology strategy: An evolutionary process perspective," Research on Technological Innovation, Management and Policy, Vol. 4, pp. 1-23, 1989.

[93] T. Bangemann, C. Bauer, H. Bedenbender, M. Diesner, U. Epple, F. Elmas, and M. Wollschlaeger, “Industrie $4.0-$ technical assets: Basic terminology concepts, life cycles and administration models," Status report, VDI/VDE, ZVEI, 2015.

[94] P. Adolphs, H. Bedenbender, D. Dirzus, M. Ehlich, and U. Epple, "Reference Architecture Model Industrie 4.0 (RAMI4.0)," Status report, VDI/VDE, ZVEI, 2015.

[95] M.A. Pisching, M.A.O. Pessoa, F. Junqueira, D.J. Filho, and P.E. Miyagi, "An architecture based on RAMI 4.0 to discover equipment to process operations required by products," Computers \& Industrial Engineering, Vol. 125, pp. 574-591, 2018.

[96] Y. Wang, T. Towara, and R. Anderl, “Topographical approach for mapping technologies in Reference Architectural Model Industrie 4.0 (RAMI 4.0)," in Proceedings of the World Congress on Engineering and Computer Science, Vol III, WCECS 2017, October 25-27, pp. 982-990, 2017.

[97] K. Schweichhart, "Reference Architectural Model Industrie 4.0 (RAMI 4.0). Platform Industrie 4.0," [Online], Available:https://ec.europa.eu/futurium/en/system/files/ged/a2-schweichhartreference_architectural_model_industrie_4.0_rami_4.0.pdf [Accessed 15 April 2021], 2019.

[98] CSIRO, "Advanced manufacturing - A roadmap for unlocking future growth opportunities for Australia," [Online], Available https://publications.csiro.au/rpr/pub?pid=csiro:EP17549 [Accessed 18 May 2021], 2016. 